УДК 349.2

DOI https://doi.org/10.32849/2663-5313/2020.1.10

\title{
Лілія Амелічева,
}

канд. юрид. наук, дочент,

доцент кафедри цивільного права і процесу

Донецького національного університету імені Василя Стуса

\section{ПРАВО НА ГІДНУ ПРАЦЮ ТРУ ДОВИХ МІГРАНТІВ В УМОВАХ ГЛОБАЛІЗАЦІї}

Стаття присвячена дослідженню змісту поняття «право на гідну прачю трудових мігрантів», виявленню деяких проблем правового регулювання права на гідну працю трудових мігрантів за міжнародними стандартами прачі та нащіональним трудовим законодавством і пошуку шляхів їх вирішення.

Виходячи з наукових доробків сучасних вчених трудового права, автор пропонує вважати змістовими складниками поняття права на гідну праню трудових мігрантів такі: право на гідні умови пращі; право на гідну оплату пращі; право на трудову честь і ділову репутащію; право на об'єктивну оиінку результатів трудової діяльності і можливість на иій основі кар'єрного росту; право на особисту недоторканість і недискримінацію; право на трудову мобільність з метою посилення повної та продуктивної зайнятості з огляду на активні глобалізачійні та євроінтеграчійні процеси в економіці.

Результатом дослідження є виявлені деякі проблеми правового регулювання гідної прачі трудових мігрантів. Так, Україна не ратифікувала ще деякі важливі Конвениії МОП, зокрема Конвениію МОП № 189 «Про гідну пращю домашніх прачівників» від 2011 року, Конвениію МОП № 19 «Про рівноправність громадян країни та іноземців у галузі відшкодування прачівникам під час нещасних випадків» від 1925 року й ін. На законодавчому рівні не стимулюється заохочення репатріації закордонних україниів, вихідиів з України та їхніх нащадків.

Обгрунтовано, що в умовах глобалізачії Україна, яка є одночасно державою походження, призначення та транзиту трудових мігрантів і позиціонє себе світовій спільноті як соціально-орієнтована держава, повинна підтримати Глобальний договір про безпечну, впорядковану й легальну міграцію (ООН). Такий крок буде стимулювати нашу країну на законодавчому рівні розробляти та вдосконалювати прочеси трудової міграчії та справедливого й етичного найму, які дозволяли б мігрантам змінювати роботодавців, умови або тривалість їх перебування з мінімальними адміністративними труднощами, а також сприяли б розширенню можливостей для гідної пращі та поліпшенню ситуащії з дотриманням норм міжнародного права щодо прав людини та міжнародного трудового права.

Ключові слова: концепція гідної праці, трудова міграція, програма гідної праці, еміграція, справедливий і етичний найм.

Постановка проблеми. Трудові мігранти роблять важливий внесок у просування сталого розвитку, але при цьому вони самі потребують підтримки й захисту у сфері гідної праці. За даними ООН, у 2019 році їх кількість у світі склала 272 млн. осіб [1]. Трудові мігранти, як й усі інші працівники, прагнуть до праці з гідними умовами, що забезпечують їм професійний розвиток, трудову честь і гідність, справедливу заробітну плату, належний рівень охорони здоров'я, соціального захисту й ін. Однак їхні трудові права не завжди забезпечені й захищені на ринку праці багатьох країн світу, що зумовлено обмеженою спроможністю урядів вживати ефективні заходи щодо транскордонної мобільності трудового потенціалу, зокрема й заходи правового характеру. Нерідко уряди деяких, навіть розвинутих, країн через розрізнений характер багатосторонньої системи міграції взагалі іï розглядають як витратну «токсичну проблему» [2].

Важливим кроком світової спільноти для вирішення цієї «токсичної проблеми» саме через підтримку й захист трудових прав мігрантів стало прийняття 19 грудня 2018 року Генеральною асамблеєю ООН Глобального договору про безпечну, впорядковану й легальну міграцію, який підписали 152 країни. Однією 323 цілей цього договору є сприяння справедливому й етичному найму і гарантування умов, що забезпечують гідну працю трудовим мігрантам, через розробку та удосконалення національних стратегій і програм, що стосуються міжнародної трудової мобільності, у тому числі 3 урахуванням відповідних рекомендацій, викладених в Загальних принципах і оперативних керівних вказівках МОП у сфері справедливого працевлаштування, Керівних 
засадах підприємницької діяльності в аспекті прав людини Організації Об'єднаних Націй та міжнародній системі сумлінного найму Міжнародної організації з міграції [3]. На жаль, Україна не підписала цей документ, пославшись на внутрішню проблему з вимушеними переселенцями.

На думку Г. І. Чанишевої, І. В. Лагутіної, Є. В. Краснова, з якою цілком погоджується й автор, що, хоча формально зобов'язання нашої держави за міжнародними договорами, положеннями Конституції та законодавством про міграцію передбачають надання рівного доступу до комплексу основних трудових прав усім легальним мешканцям країни, мігранти все одно позбавлені можливостей повною мірою скористатися своїми трудовими правами через відсутність належних механізмів імплементації та суперечливе тлумачення щодо застосування цих положень. Тому мігранти виявилися незахищеними від економічної та соціальної маргіналізації [4]. Отже, проведення правового аналізу забезпечення гідних умов праці (або права на гідну працю) трудових мігрантів за міжнародними стандартами праці, за законодавством України є необхідним і своєчасним, особливо під час багаторічного впровадження програми гідної праці МОП для України й прийняття світовою спільнотою Глобального договору про безпечну, впорядковану й легальну міграцію.

Аналіз останніх досліджень і публікацій. Питання реалізації та захисту права на працю трудових мігрантів у його традиційному розумінні в науці трудового права останнім часом досліджували О. І. Кисельова [5], О. А. Трюхан [6], Н. М. Швець [7] та ін. Що ж до проблематики правового забезпечення права на гідну працю трудових мігрантів, то вона в сучасній спеціальній юридичній літературі висвітлюється лише за деякими аспектами, не системно [8; 9].

Метою дослідження $є$ уточнення змісту поняття «право на гідну працю трудових мігрантів», висвітлення деяких проблем правового регулювання права на гідну працю трудових мігрантів за міжнародними стандартами праці й національним трудовим законодавством та пошук шляхів ї вирішення.

Виклад основного матеріалу. За даними Міжнародної організації праці, близько 21 мільйона трудових мігрантів, включаючи дітей, нині є жертвами практики неетичного та нечесного найму, в них фактично відбирається можливість мати право на гідну працю [10]. Такий стан викликаний різними причинами, зокрема й правовими.
Перш ніж розпочати дослідження причин неналежного правового забезпечення права на гідну працю трудових мігрантів, необхідно з'ясувати сутність понять «трудова міграція», «право на гідну працю трудових мігрантів».

Враховуючи, що для України явище трудової міграції досить нове, з’ясуємо його змістове наповнення, аналізуючи спеціальну юридичну літературу. Так, в юридичній енциклопедичній літературі під трудовою міграцією (лат. migratio - переселення) розуміється соціально-правове явище, яке характеризується переміщенням працездатного населення як усередині країни, так і за їі межами під впливом негативних економічних чинників у пошуках роботи на певний термін. Вирізняють зовнішню (міжнародну) та внутрішню трудову міграцію [11, c. 693-694].

На думку О. А. Трюхан, з якою цілком погоджується й автор, трудову міграцію слід розглядати у значенні права на трудову міграцію. Вчена зауважує, що до змісту права на трудову міграцію входять: право приймати реально запропоновану роботу; право вільно пересуватися в цих цілях територією держав-членів співтовариства; право перебувати в одній із держав-членів співтовариства, займаючись трудовою діяльністю відповідно до законодавства, що регулює зайнятість громадян даної держави співтовариства; право залишатися на території однієї з держав-членів співтовариства після завершення трудової діяльності в цій державі на визначених співтовариством умовах [6, с. 178]. У світлі концепції гідної праці, ініційованої МОП як спеціалізованою інституцією ООН [12], необхідно доповнити перелік правоможностей права на трудову міграцію, запропонований О. А. Трюхан, і правом трудових мігрантів на гідні умови праці (або на гідну працю). Адже забезпечення гідної праці для всіх, у тому числі трудових мігрантів, є однією 3 найважливіших цілей майбутнього розвитку світової спільноти, що задекларовані у вересні 2015 року в рамках 70-ї сесії ГА ООН у Нью-Йорку на Саміті ООН зі сталого розвитку у підсумковому документі «Перетворення нашого світу: порядок денний у сфері сталого розвитку до 2030 року» (Цілі Сталого Розвитку або ЦСР) [13]. А саме, ціль 8 ЦСР - сприяти сталому, інклюзивному та стійкому економічному зростанню, повній та продуктивної зайнятості та гідній праці для всіх.

Далі слід зауважити, що розуміється під правом на гідну працю кожного, зокрема працюючого мігранта. На думку В. В. Жернакова, 3 якою не можна не погодитися, 
у праві кожного на гідну працю можна виокремлювати такі складники, як право на гідні умови праці, право на гідну оплату праці, право на трудову честь і ділову репутацію, право на об'єктивну оцінку результатів трудової діяльності і можливість на цій основі кар'єрного росту; право на особисту недоторканість і недискримінацію тощо [14, с. 98]. Враховуючи контекст даного дослідження, до складників права на гідну працю, запропонованих зазначеним вченим, можна було б додати й ще один важливий складник право на трудову мобільність з метою посилення повної та продуктивної зайнятості, враховуючи активні глобалізаційні та євроінтеграційні процеси в економіці.

Отже, трудова міграція для України $€$ масовим явищем, адже наша країна одночасно $є$ державою походження, призначення та транзиту працівників-мігрантів, територією різнохарактерних, різноспрямованих та різномасштабних трудових міграційних потоків. Зазначене зумовлює те, що національна нормативно-правова база, яка регулює трудові відносини 3 трудовими мігрантами у сфері гідної праці, є вагомою, чисельною та різноманітною, але не в усьому досконалою. Тому забезпечення державного, зокрема державно-правового, регулювання у сфері трудової міграції є складним завданням, розв'язання якого потребує комплексного, системного підходу, належного фінансування, нормативно-правового, кадрового та наукового забезпечення.

Далі необхідно зазначити більш детально правові засади в Україні у сфері права на гідну працю трудових мігрантів.

Трудові відносини 3 іноземцями або апатридами в Україні регулюються ст. 26 Конституції України, положеннями ратифікованих нашою державою міжнародних та європейських стандартів праці, таких як: Конвенція ООН «Про захист прав усіх трудящих-мігрантів та членів їх сімей» від 1990 року, Конвенція МОП № 97 «Про працівників мігрантів» від 1949 року, Конвенція МОП № 143 «Про зловживання в галузі міграції і про забезпечення працівникаммігрантам рівних можливостей i рівного ставлення» від 1975 року, Конвенція МОП № 111 «Про дискримінацію в галузі праці та знань» від 1958 року, Свропейська конвенція про правовий статус трудящих-мігрантів від 1977 року, Свропейська соціальна хартія (переглянута) від 1996 року та ін. Також відносини з трудової еміграції (трудова еміграція - переселення працездатного населення 3 країни походження в іншу державу, а також тривале або тимчасове перебування за межами країни походження з метою пра- цевлаштування) [11, с. 693] врегульовані двосторонніми міжнародними договорами між Україною та Польщею, Чехією, Італією, Іспанією, Португалією й ін.

Слід зауважити, що правовий статус трудових мігрантів за чинним КЗпП України та іншим трудовим законодавством є ідентичним із статусом громадян України, але за умови, якщо перебування іноземця на території України відповідає вимогам Закону України «Про правовий статус іноземців та осіб без громадянства», Закону України «Про зайнятість населення», Закону України «Про імміграцію», Закону України «Про внесення змін до деяких законодавчих актів України щодо боротьби з нелегальною міграцією», а також чисельних підзаконних актів, які регламентують питання перебування іноземців в Україні, оформлення для них дозволу на працевлаштування роботодавцями й ін. Одним із важливих законів, що визначає правові та організаційні засади державного регулювання зовнішньої трудової міграції та соціального захисту громадян України за кордоном (трудових мігрантів) і членів їхніх сімей, є Закон України «Про зовнішню трудову міграцію». Також слід назвати деякі підзаконні акти концептуального характеру з питань міграції, зокрема із зовнішньої трудової міграції, а саме: Стратегію державної міграційної політики України на період до 2025 року, Програму гідної праці МОП для України на період 2016-2019 рр. й ін.

Вченими трудового права слушно зауважується, що натепер в Україні відсутній базисний законодавчий акт, який би відображав засади всієї державної міграційної політики України. У зв'язку з цим пропонується прийняття Закону України «Про основні засади державної міграційної політики України», який дозволить зміцнити механізми захисту прав та інтересів суб'єктів міграційних процесів для покращання демографічної та соціально-економічної ситуації в Україні та зможе розв'язати проблему щодо визначення на законодавчому рівні основних засад державної міграційної політики України та напрямів іï реалізації [4]. Разом iз тим у такому документі, на наш погляд, необхідно передбачити і механізм правового забезпечення права на гідну працю трудових мігрантів.

У контексті цього дослідження необхідно розглянути деякі важливі документи стратегічного і концептуального характеру.

Так, у Стратегії державної міграційної політики України на період до 2025 року суттєвою проблемою встановлено імміграцію висококваліфікованих фахівців та молоді 
у тому числі внаслідок неповернення на Батьківщину після отримання освіти за кордоном, яка зростає через політику ряду держав щодо залучення висококваліфікованих іммігрантів, молодих фахівців із числа іноземних студентів. У свою чергу, втрата Україною таких категорій працівників негативно позначається на віковій та освітньо-кваліфікаційній структурі робочої сили і може гальмувати економічне зростання. У зазначеній Стратегії пропонується розробка в найближчий час програм заохочення репатріації закордонних українців, вихідців з України та їхніх нащадків й ін.

В іншому документі концептуального характеру - Програмі гідної праці МОП для України на період 2016-2019 рр. - зауважується, що умови праці українських трудових мігрантів далекі від гідних, є численні випадки несправедливого й неетичного найму, що є причиною для занепокоєння. Згідно 3 результатами обстеження, лише 38 відсотків трудових мігрантів уклали письмовий трудовий договір 3 іноземними роботодавцями. Здебільшого письмовий трудовий договір між трудовими мігрантами та роботодавцями був укладений мовою країни працевлаштування, і тільки у 25 відсотках випадків його було перекладено українською. Особливо вразливими до порушень своїх трудових прав є ті трудові мігранти, які працюють домашніми працівниками (18,3% від загальної кількості трудових мігрантів). Ця категорія українських мігрантів (переважно жінки), як правило, не формалізуе свої трудові відносини (у 16,5 відсотках випадків) у письмовій формі (10-11) [15]. У зазначеній Програмі сформульовані пріоритети у державній соціальній політиці 3 питань трудової міграції (підготовка до ратифікації ряду Конвенцій МОП, зокрема, про гідну працю домашніх працівників й ін.). Таким чином, позитивним досягненням нині у державній соціальній політиці 3 питань забезпечення гідної праці трудових мігрантів є чітке розуміння законодавцем, Урядом того, за якими напрямами його вдосконалювати, виходячи зі Стратегії державної міграційної політики України на період до 2025 року, зокрема, у сфері трудової міграції, Програми гідної праці МОП для України на період 2016-2019 рр. До того ж натепер вже визначені пріоритети наступного документа Програми гідної праці МОП для України на період 2020-2024 рр. [16], який також буде позитивно впливати на удосконалення національного трудового законодавства, що регулює трудові відносини у сфері гідної праці для всіх працівників, у тому числі трудових мігрантів.

\section{Висновки}

1. Виходячи з наукових доробків сучасних вчених трудового права, пропонується вважати змістовими складниками поняття права на гідну працю трудових мігрантів такі: право на гідні умови праці; право на гідну оплату праці; право на трудову честь і ділову репутацію, право на об'єктивну оцінку результатів трудової діяльності і можливість на цій основі кар'єрного росту; право на особисту недоторканість і недискримінацію; право на трудову мобільність з метою посилення повної та продуктивної зайнятості з огляду на активні глобалізаційні та євроінтеграційні процеси в економіці.

2. Результатом дослідження є виявлені деякі проблеми правового регулювання гідної праці трудових мігрантів. Так, Україна не ратифікувала ще деякі важливі Конвенції МОП, зокрема Конвенцію МОП № 189 «Про гідну працю домашніх працівників» від 2011 року, Конвенцію МОП № 19 «Про рівноправність громадян країни та іноземців у галузі відшкодування працівникам під час нещасних випадків» від 1925 року й ін. На законодавчому рівні не стимулюється заохочення репатріації закордонних українців, вихідців з України та їхніх нащадків.

3. В умовах глобалізації Україна, яка $€$ одночасно державою походження, призначення та транзиту працівників-мігрантів й позиціонує себе світовій спільноті як соціально-орієнтована держава, повинна підтримати Глобальний договір про безпечну, впорядковану й легальну міграцію $(\mathrm{OOH})$. Такий крок буде стимулювати нашу країну на законодавчому рівні розробляти та вдосконалювати процеси трудової міграції та справедливого й етичного найму.

\section{Список використаних джерел:}

1. International Migration 2019 Wall Chart / Department of Economic and Social Affaires. Unaited Nations. URL: https://goo-gl.su/MqzJH (дата звернення: 15.12.2019).

2. Promoting decent work for migrant workers. ILO / Website Global Forum on Migration and Development (Geneva, Switzerland on 5 February 2015), P. 4. URL: https://goo-gl.su/jXeY (дата звернення: 15.12.2019).

3. Глобальный договор о безопасной, упорядоченной и легальной миграции. Межправительственная конференция для принятия глобального договора о безопасной, упорядоченной и легальной миграции. Марракеш, Марокко, 10 и 11 декабря 2018 года. URL: https://goo-gl.su/hwW4 (дата звернення: 15.12.2019).

4. Чанишева Г.І. та ін. Місце трудових та соціально-забезпечувальних прав у системі прав людини. Наукові пращі Наиіонального 
університету «ОЮА». Т. 17 / голов. ред. С. В. Ківалов; МОН України, НУ «ОЮА». Одеса, 2015. С. 201-231. URL: https://goo-gl.su/ EB0С74ру (дата звернення: 15.11.2019).

5. Кисельова О.І. Трудова міграція: суть і причини виникнення. Науковий вісник Ужгородського національного університету. Серія «Право». 2013. № 21. Ч. 1. С. $60-63$.

6. Трюхан О.А. Право працівників - мігрантів на зайнятість: міжнародні стандарти і законодавство України. Часопис иивілістики. 2015. № 19. С. $178-184$.

7. Швець Н.М. Окремі правові аспекти трудової міграції. Журнал східноєвропейського права. The Journal of Eastern European Law. 2018. № 47. C. 152-164.

8. Амелічева Л.П. Деякі проблеми правового забезпечення гідної праці трудових мігрантів. Тендениї розвитку науки трудового права та права сочіального забезпечення: тези допов. учас. міжнар. наук.-практ. конф. (2 квітня 2019 р.) / за ред. проф. М.І. Іншина, Київ, 2019. С. 7-10.

9. Амелічева Л.П. Правове регулювання справедливої зайнятості та гідної праці трудових мігрантів, постраждалих внаслідок конфліктів і лих. Порівняльно-аналітичне право. 2019. № 4. С. 178-181.

10. Международная система добросовестного найма иностранной рабочей силы : Брошюра
Представительства Международной организации по миграции (MOM). Женева. URL: https:// goo-gl.su/LZbxuxJ (дата звернення: 12.12.2019).

11. Велика українська юридична енциклопедія :у 20-ти т. Том 11. Трудове право. Право. 2018. 776 с

12. Достойный труд. Доклад Генерального директора Международного бюро труда (МБТ) на 87-й сессии Международной конференции труда. Женева : Международная организация труда, $1999.58 \mathrm{c}$

13. Доклад о Целях в области устойчивого развития. 2017 г. / Организация Объединенных Наций, Нью-Йорк. C. 7. URL: https://goo-gl.su/ mocg (дата звернення: 12.12.2019).

14. Жернаков В.В. Право на гідну працю: питання формування і забезпечення. Розвиток трудового права $i$ права соиіального забезпе чення: теорія і практика : тези доп. та наук. повідомл. учасників VIII Міжнар. наук.-практ. конф. (м. Харків, 5 жовт. 2018 р.) / за ред. О. М. Ярошенка. Харків, 2018. С. 95-99.

15. Програма гідної праці МОП для України на період 2016-2019 рр. від 07.04.2016. URL: https:// goo-gl.su/6sXCiOqP (дата звернення: 15.12.2019).

16. Визначено пріоритети Програми гідної праці МОП на 2020-2024 роки / Міжнародний департамент КВПУ. Конфедерація вільних профспілок України. 20.12.2019. URL: https://goo-gl. su/wfe7svTC (дата звернення: 11.12.2019).

The article is devoted to research of the notion «the right to decent work of migrant workers», identifying some of the problems of legal regulation of the right to decent work for labour migrants, international labour standards and national labour legislation, ways of their solution.

On the basis of scientific works of modern scientists labor law, the author proposes to consider meaningful components of the concept of the right to decent work of migrant workers, the following: the right to decent working conditions; right to fair wages; right to labour honour and business reputation; the right to objective evaluation of results of labour activity and the ability on this basis for career development; right to personal integrity and non-discrimination; the right to labour mobility in order to enhance full and productive employment, taking into account the active globalization and European integration processes in the economy.

The result of the study is to identify some problems of legal regulation of decent work of migrant workers. Thus, Ukraine has not yet ratified some important ILO conventions, in particular, ILO Convention No. 189 «On decent work for domestic workers» of 2011, ILO Convention No. 19 «On equality of citizens and foreigners in the field of compensation for workers in accidents» of 1925, etc. There is no incentive to encourage the repatriation of foreign Ukrainians, immigrants from Ukraine and their descendants at the legislative level.

It is proved that in the conditions of globalization, Ukraine, which is both a state of origin, destination and transit of labor migrants and positions itself in the world community as a socially-oriented state, should support the Global Treaty on safe, well-organized and legal migration (UN). Such a step will encourage our country to develop and improve at the legislative level the processes of labour migration, fair and ethical employment, which would allow migrants to change employers, conditions or duration of their stay with minimal administrative difficulties, as well as to enhance opportunities for decent work and improve the situation with respect to international human rights law and international labour law.

Key words: decent work concept, labor migration, decent work program, emigration, fair and moral employment. 